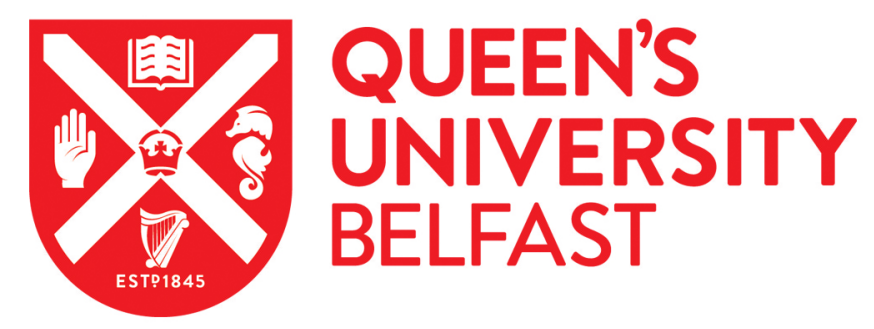

\title{
The Subcontinent as Spectator Sport: The Photographs of Hariot Lady Dufferin, Vicereine of India
}

Litvack, L. (2006). The Subcontinent as Spectator Sport: The Photographs of Hariot Lady Dufferin, Vicereine of India. History of Photography, 30 (4)(4), 348-358.

Published in:

History of Photography

Document Version:

Publisher's PDF, also known as Version of record

Queen's University Belfast - Research Portal:

Link to publication record in Queen's University Belfast Research Portal

\section{General rights}

Copyright for the publications made accessible via the Queen's University Belfast Research Portal is retained by the author(s) and / or other copyright owners and it is a condition of accessing these publications that users recognise and abide by the legal requirements associated with these rights.

Take down policy

The Research Portal is Queen's institutional repository that provides access to Queen's research output. Every effort has been made to ensure that content in the Research Portal does not infringe any person's rights, or applicable UK laws. If you discover content in the Research Portal that you believe breaches copyright or violates any law, please contact openaccess@qub.ac.uk. 


\title{
The Subcontinent as Spectator Sport: The Photographs of Hariot Lady Dufferin, Vicereine of India
}

\author{
Eadaoin Agnew and Leon Litvack
}

\begin{abstract}
Hariot Lad! Dufferin (18+3-1936) accompanied her husland to India during lis Vicergency (1884-1888). W/yile there she took up photography as a leisure activity in order to capture for posterity views of a country she greatly admired. This essay examines, from a post-colonial perspective, her private collection of pholographs, encompassing landscapes, people, imperial açuisitions and more personal spaces. Using a foucaultian argument, it considers how these photographs help to define the Vicereine's subject position, as an upper-class woman at the very centre of British rule in lndia, who was both surveyor and surveyed: she was privileged, vet, owing to the confines of gender, unable to express in written form any views on the affairs of state. Photography, however, offered her a useful ristal language through which she could engage with the discourses of empire.
\end{abstract}

Keywords: Hariot Gcorginn Hamilson Temple-Blackwood, Marchioness of Dufferin and Ava (1843-1936), Lndia, British Empirc, post-colonialism, Michel Foncrult (1926-1984)

Hariot Georgina Hamilton Temple-Blackwood, Marchioness of Dufferin and Ava (1843-1936) (figure 1), was Vicereine of India from 1884 to 1888 . She had previously accompanied her husband, Frederick Temple Hamilton-TempleBlackwood, first Marquess of Dufferin and Ava (1826-1902), on other foreign postings: Canada (1872-1878), St Petersburg (1879-1881) and Constantinople (1881-1884). She was an experienced, popular ambassador, resilient, zestful, attentive, shrewd and kind, and never blase about her official duties. In India she travelled extensively, entertained generously and founded the National Association for Supplying Female Medical Aid to the Women of India.' She learned Hindustani and developed a keen interest in photography-partly to provide her with an interesting pastime and partly to record, for both public and private consumption, her experiences on the subcontinent, a place where she played a significant role in introducing Western ideas about hygiene and medicine into many parts of India, thus saving many lives.

in this context, photography might at first seem to be an innocuous activity-a hobby in which the Vicereine could engage to while away the hours when her husband was occupied by' affairs of state-a masculine realm that was closed to women. She also used some of her time to write highly descriptive and detailed letters home to her mother, Catherine Anne Rowan Hamilton; on her return from India she collected these into a volume entitled Our Viceregal Life in India (hereafter OVL), published in 1889. 2 The travelogue is well known, but

J - This establishment was often knoun is the Countess of Dufferin Fund. Its purp se was to relieve the suffering, through illness and childbearing, of Indian women. Her plan was to recruit and train women doctors, nurses and miduives 10 provide medical advice and attendance under conditions which respected patients" wishes. With gentle, persistent authority she presided over countless fund-raising metings; by the time she left India her scheme had heen adopted in every province, and there were Countess of Dufferin Fu-d hospitals and dispensarics for women in all the principal states. This great act of constructive charity wat commemorated by Rudyard Kipling in his 'Song of the Nomen' (1886).

2- Our Viceregal Lifc in India: Sclecrions from M) Journal, 188+1888, by we Marchoness of Dufferin and Ava, 2 vols. London: John Murray 1889. The volumes were compiled from the latters Lady: Dufferin sent to her mother, Catherine Ante Rowan Hamilton (1820-1919). 
F. ure 1. Frontispicce to Our Viceregal Life depicting Lady Dufferin. Our Vicartyal L.tft in loulat Selections from wy Journal, J884$1 \times 48,2$ vols, London: John Murray 1889.

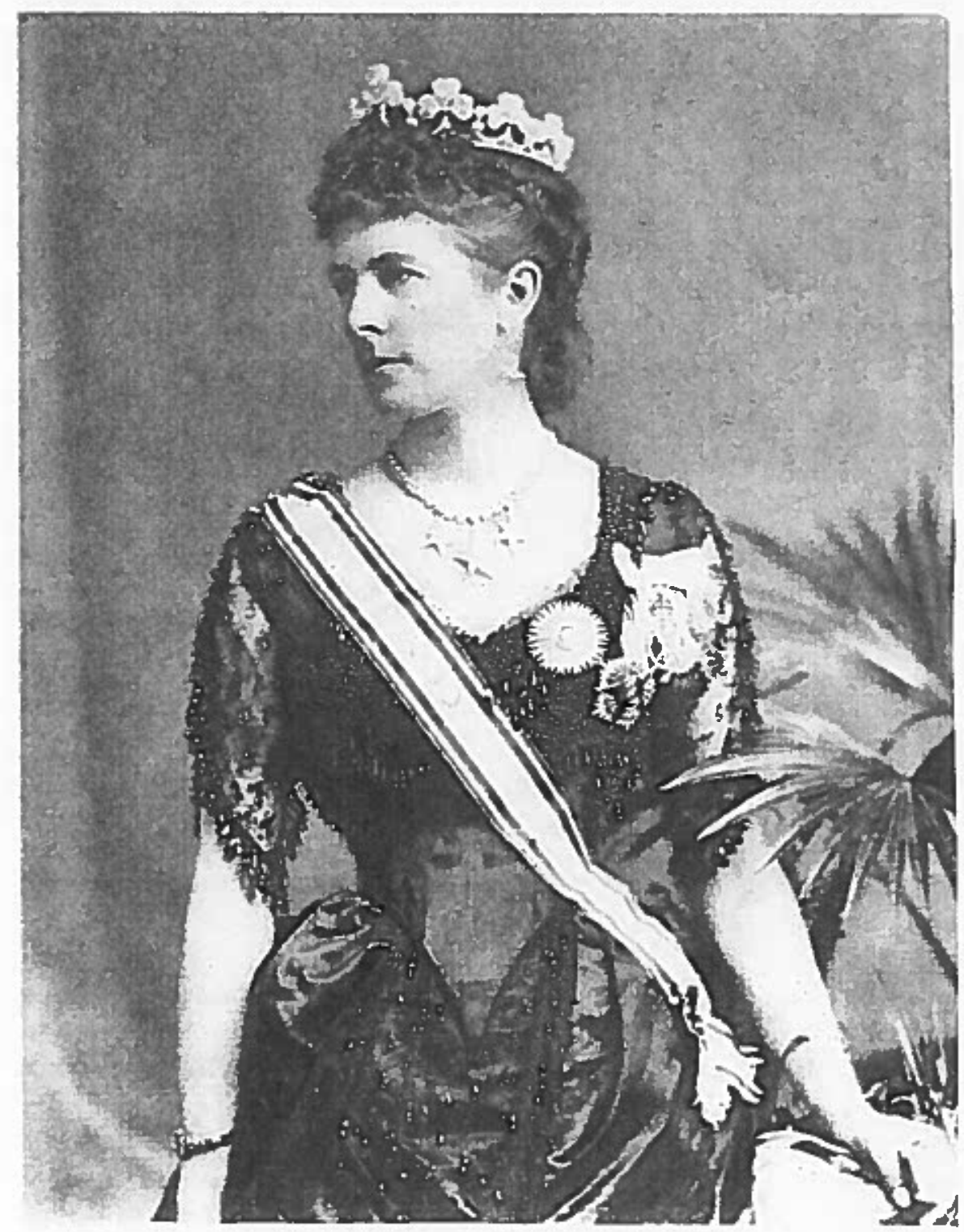

Lady Dufferin's private collection of photographs (housed in the Public Record Office of Northern Ireland) is not. ${ }^{3}$ Within a masculine domain, photography became an important instrument for disseminating knowledge alsout the character of India: it was pressed into service to compile inventories and aid scholarly research, to catalogue the vast collection of humanity that constituted the indigenous population, to record landscapes for official topographical surveys, to document important architectural monuments, and, ultimately, to reinforce British rule of the subcontinent. ${ }^{+}$The Vicereine's photographs complied with some of these aims; but they should be read and analysed in a slightly different way.

In her study of women's travel writing, Sara Mills explains that, while women were as involved in the colonial enterprise as men, they were unable to be explicit in their descriptions of it because of 'discursive constraints'. It is clear how this limitation applies to the travelogue, which includes, for example, passages on domesticity and dress. Photographs, however, constitute a different mode of expression. In Britain or Ireland, Lady Dufferin was more likely to be located as the object of surveillance by masculine powers; as Vicereine in India, however, her situation became more complicated: she was both surveyed and surveyor. ${ }^{6}$ This dichotomous position, according to Cheryl McEwan, is one in 
which many women who travelled to the outposts of empire found themselves: they were both acted upon and acting. ${ }^{7}$ While Lady Dufferin was collecting images herself, there were also several official viceregal photographers who were observing and recording images of her and her husband; one of these was Lala (or Raja) Deen Dayal (1844-1905), a pioneer in his field in India. ${ }^{B}$ In her letters the Vicereine often acknowledges the presence of both official and unofficial photographers. Thus, as she surveyed and represented what she saw as supporting and reinforcing imperial power, her behaviour was also under scrutiny and would necessarily have been monitored and self-regulated.

As someone who invited immense attention wherever she went, Lady Dufferin was obviously much photographed, as she remarked on arrival in India: "The number of frightful caricatures of us which is being called into existence is fearful, for we never move anywhere that we don't see a photographer pointing at us from the top of a carriage, or from some unexpected vantage-ground' (OVL 1.8). Though this remark might understandably indicate an aversion to this level of public scrutiny, it does point to how photography can offer privileged points of access or observation from which to record, through mechanical means, authoritative images of the things observed, and, in the process, to possess them imaginatively. As Vicereine, Lady Dufferin sometimes had the added opportunity physically to acquire the items photographed, as 'possessions' or 'spoils' of empire.

The Vicereine's own use of the camera became an important element in the construction of her identity: she moved within colonial spaces largely as a spectator who could adopt a detached but elevated position, exuding superiority while remaining within the acceptable boundaries of late $V$ ictorian femininity. The way in which a photograph can be framed may be an important indicator of the dynamic between coloniser and colonised. Indeed popular aesthetic tropes of the panoramic and the picturesque could be used to reinforce the power relations upon which empire depended. As Walter Benjamin has noted, photographs can put the copy of the original into situations which would be out of reach for the original itself; he adds that their authenticity and historical testimony are interfered with, so that the authority of the object is jeopardised. ${ }^{9}$ This is true, for example, of Lady Dufferin's depictions of Mandalay, in Burma. The last Myanmar kingdom was annexed by Britain during Lord Dufferin's viceregency, and the last rulers, King Thibaw and his Chief Queen Supayalatt, were dispatched to India. ${ }^{10}$ Lord and Lady Dufferin visited Mandalay in February 1886. She relates in her journal that she amused herself with photography (OVL 1.321), taking possession-both literally and figuratively - of her empire's newest acquisition. The photograph of the palace (figure 2) is, of course, posed, and so juxtaposes the building with actors and actresses, in order to create an ostensibly 'authentic' view (requiring two to five seconds exposure on the photographic plate); yet it lacks a presence in time and space: its unique existence at the place where it happens to be fails to give an idea of the history to which the individuals depicted were subject. What remains is a manufactured image that has been exoticised by its transplantation, both physical and imaginative, out of the historical moment in which it was conceived; it becomes merely what Lady Dufferin has labelled it in prose: she says that that "this sort of play would make an admirable successor to the "Mikado" if it could be produced in London' (OVL 1.318).

At the palace, which Lady Dufferin dubs her 'Prize' (OVL 1.315), she speaks of arriving as 'King and Queen' (OVL 1.307), as the local dignitaries pay homage to the new occupying power; indeed Lord Dufferin, in the role of imperial aggressor and conqueror, sat on the throne that had been vacated by King Thibaw (figure 3 ). The Vicereine believed that the prize was not as grand
7-Cheryl McEwan, Genfer, Geograply und Empire: Victorian liomen Travellers in ly est Africa, Aldershot: Ashgate 2000, 163-1:5. 8 - Lala Deen Dayal received technical training at Thomson's Civil Engineerin College at Roorkee, and in 1866 beeame an cstimator and draughtsman in the Department of Public Works in Indore He developed a keen interest in photograp and was encouraged by Sir Henry Dal the Agent to the Governor General for Cet - ral India; Daly assigned him the task of photographing the royal visit of the $\mathrm{Pr}$ ce of wales in 1875 . Impressed by his tale $t$ Daly took Dayal along with him on his our of Bundelkhand. In 1882-83 Dayal agn toured Bundelkhand with Sir Lepel Gr in who was then the Agent; eighty-rine of his photographs of palaces, forts and templ $s$ in Gwalior, Khajuraho, Rewa and Sanchi ere splendidly reproduced by the autotype catbon process in Griffin's Famous Monuments of Central Indir, London 186. The year before this book was publishet Dayal had the opportunity to photogr. th Lord Dufferin and Lady Dufferin. So pleased were they with the pictures tha Dayul was appointed photographer to the V'iceroy. Dayal then tetired from government serice and became court photographer to the Nitam of $\mathrm{Hyd}$ derat d. He frequently photographed visiting for agn dignitaries such as the Russian Carathe the Crown Prince of Germany. He had photographic exdibitions in London, and in 1897 wis granted a royal wirrant by Quect Victoria. For examples of Dayal's work ce Raja Decn Dayul: Prince of Photographes, Hyderabad: Creative Print 2003. Sec als I Lala Decu Dayal: The Emincme Indian Photographer 1844-1910, London: 1ibr ies and Arts Department 1982. Dayal's photngraphs are distinctive, because thet provide a 'luxuriously incongruous me ing point' herween two vastly different cultures that had begun to interact'; they are als: charactcrised by aesthetic elegance: the were carefully planned and composed $\mathrm{s}(\mathrm{s})$ to scem 'deceptively natural' (Princly I tilia: Photographs by Raja Decn Dajal 18gt-1910. a. Clark Worswick, New York: Penwik Publishing 1980, 22). Unfortunately nore of these volumes features images of the Dufferins.

9- Walter Benjamin, 'The Work of Art in the Mechanical Age of Reproduction', in Mhuninations, ed. Hannah Arendt, Net York: Schoken Books 1969, 220-221. 10- The merchants of Rangoon, long envious of royal monopolics that restricted trade, started agitating for annexation. The French government had signed a commercial treaty with king Thibaw, in order to extend their Indo-Chinese protectorate to the Indian border. This move antagonised the British, and the Viccroy issued an ultimatum which called for a British protectorate. In a show of bravado, King Thibaw rejected the ultimatum and declared war in Octobe: 1885. Ten thousand British troops marced 


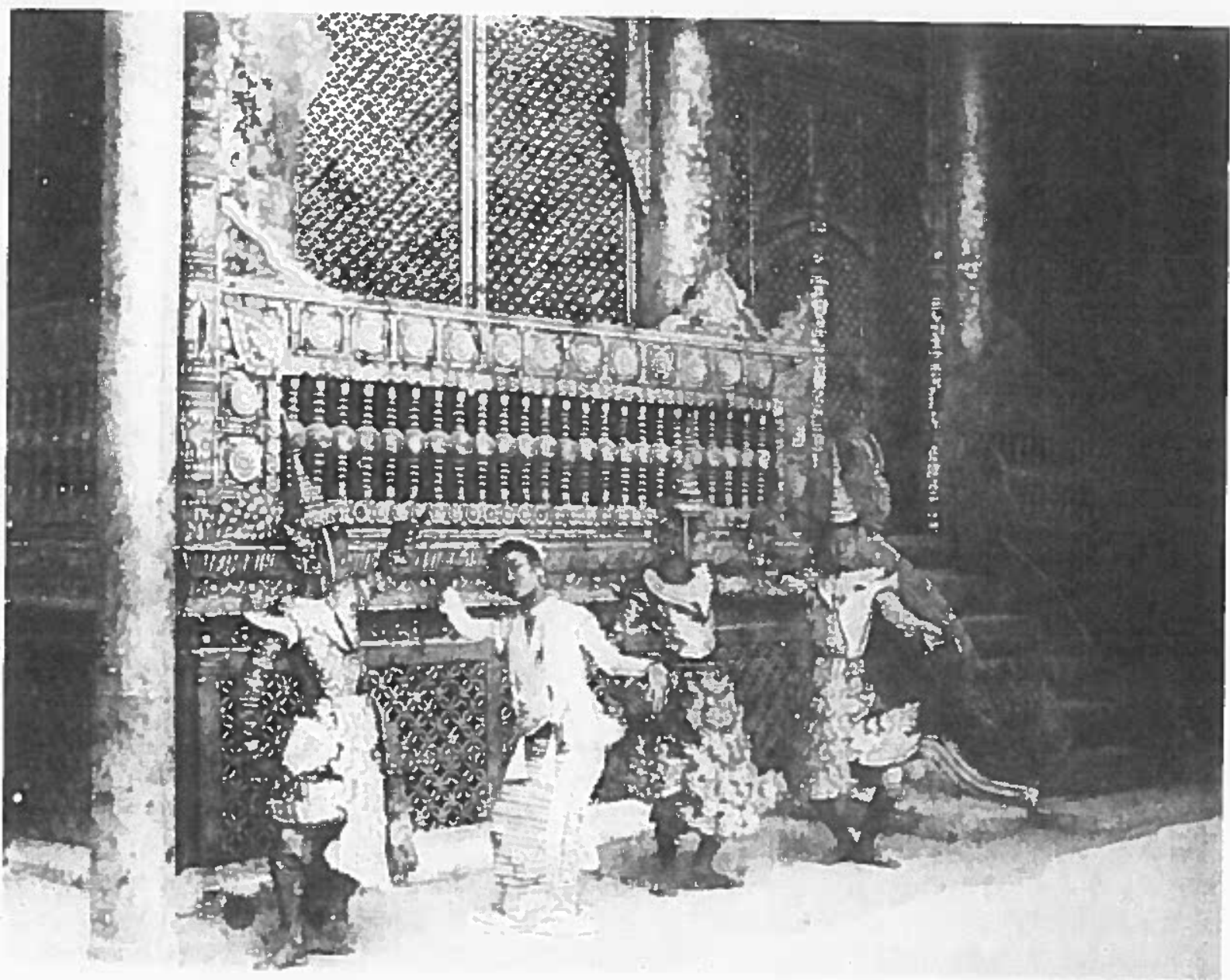

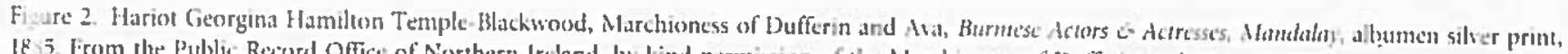
If 5. From the Public Record Office of Northern Ifeknd, by kind permission of the Marcliweness of Dufferin and Aha.

fr In Rangonn, and by Novelnter 1885 , Mindalay wats occupied. Thibaw and his ir andiate family went into exile in India an he ended his days in a small brick $p$ ace at Ratnagiri in 1916

11 - Dufferin letter, 15 February 1886,13 , Publie Record Office of Northern Ireland; D. $107 \mathrm{U} / / \mathrm{C} 1 / 8$.

12- For in interesting antalysis of the efforts b a later Viceroy, Lord Curzon, to chistruct a visible memory lndia under B itrish rule, sce Thomas R. Metcalf,

Monuments and Memorials; Lord Curzon's. Creation of a Past for the Raj', in Traces of Hilit, 242-259. The imperial legacy of the p. Jace at Mandalay lasted well into the thentieth century in the final phase of the Seiond World War, Myanmar again stofitered heavy damage and destruction. As it : Allied forces advanced and the Japanese in reated, both parties bombed Myanmar ct:ies and towns indiscriminately. In 1945 if . Nlies shelled and burned down

Indalay Palace, which was occupied by

1 banese forces. as she had wished, because, as she notes in her published journal, most of the spoils had been removed by King Thibaw's subjects before the British arrived (OVL 1.315-316). However, in the original letter, preserved in the Public Record Office, the extent to which Lady Dufferin salw Burma as hers for the taking becomes apparent; she writes:

We looked at the "Prizes." Very poor prizes they are! [... We wanted to choose something for the Princess of Wales, but there is nothing. We shall profit inditectly by this conquest for we shall get carpets and chandeliers and mirrors for the new Government house at Simla, and a few pieces of nice China and wo handsome Siamese mirrors for the Calcutta House, which hitherto has been sadly destitute of orrament."

When combined with the photograph of the actors, these lines indicate the extent to which the Vicereine wished to possess Mandalay-both materially and metaphorically. In the photograph she is able to capture a flecting moment, the reality of which would be forever erased by the advancing colonising force. Thibaw's history is swept aside by the transformatory impulse of imperialism; the palace, built of teak, gilt, vermillion, and glass mosaic, was ransacked by the British forces: royal audience halls, throne rooms and chambers were turned into garrison, church, club and military quarters and barracks. From 1885 to 1901 the whole palace complex was subjected to vandalism, abuse and neglect: some buildings became so dilapidated through plunder that they had to be destroyed. Thus, what Lady Dufferin captured as the authentic condition of the palace at Mandalay was immediately altered and changed forever by imperial acquisition. ${ }^{12}$ 


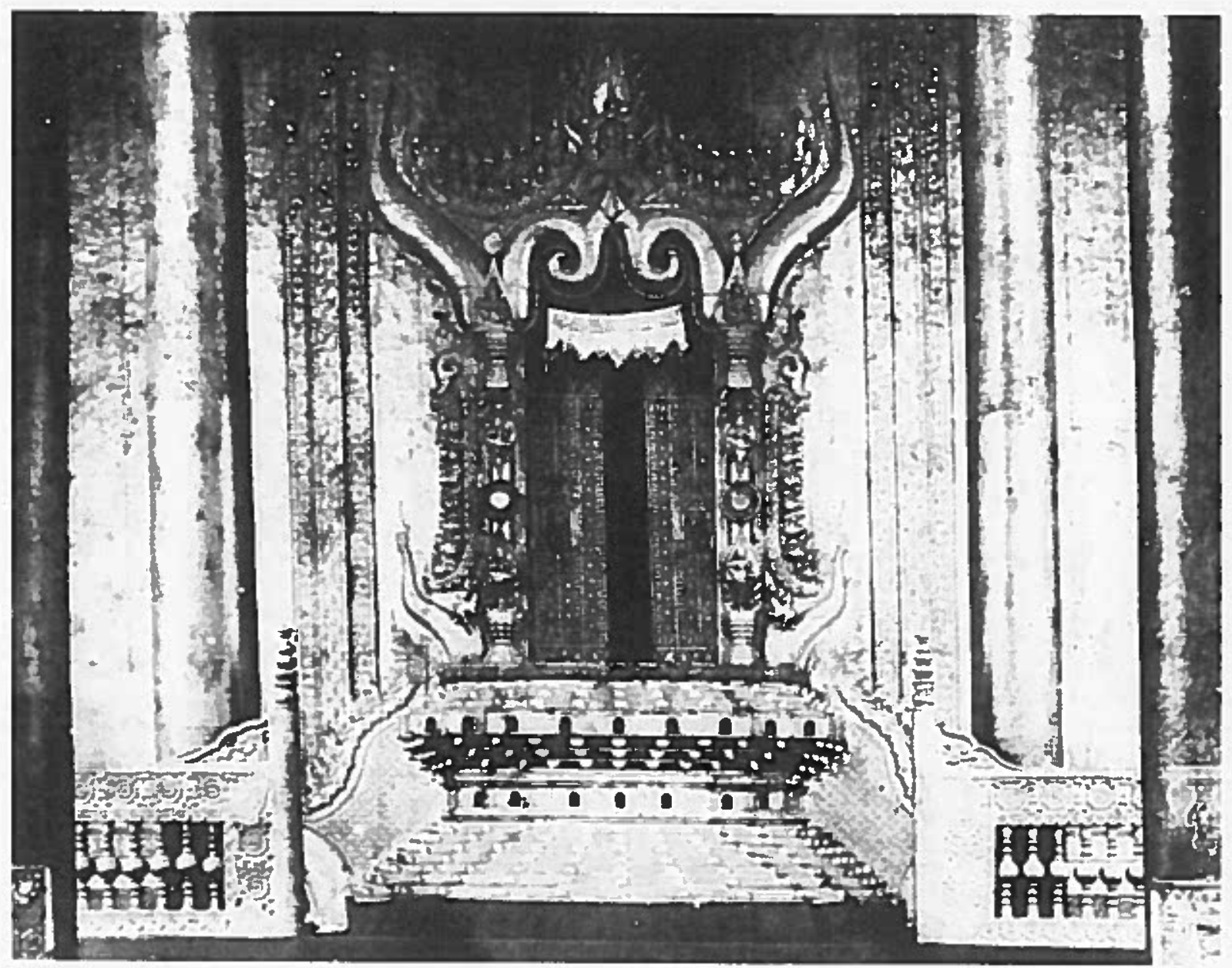

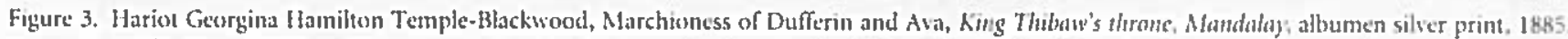
From the I'ublic Record Office of Northern Iretand, by kind permission of the Marchioness of Dufferin and Ava.

Landscape photography constituted another important genre for Lady Dufferin. While other members of her family turned to painting to record their impressions, she was interested in taking 'a few views' (OVL 1.189), aided by an instructor in photograply, who guided her in the more technical aspects of this science. $^{13}$ Landscape photography in particular confirms the Foucaultian correlation between knowledge and power that Susan Sontag evokes in her pronouncements on the subject: 'To photograpls is to appropriate the thing photographed. It means putting oneself into a relation to the world that feels like knowledge-and, therefore, like power'.'4 Lady Dufferin's favoured vantage point for views of the Indian landscape was from above; she was constantly aware of altitude, particularly in Simla, where she remarks several times in her journal on whose house is situated either above or below that of the Viceroy. In photographic terms, it is possible to see an elevated angle of framing as adopting a hierarchical perspective on the colonial world. Roland Barthes, in his essay on the Eiffel Tower, remarks that this universally recognisable monument serves as a 'lookout' from which to observe human space, combining panoramic vision with an incomparable power of intellection which can be used to analyse the world. Lady Dufferin's Himalayan perspective may be read in a similar way: it offers a 'polyphony of pleasures' for the colonial observer, who can simultaneously feel cut off from the world and yet the owner of the world'. ${ }^{15}$

Barthes also discusses the panoramic, which he characterises as a teuphoric vision', but one which engages the mind in a struggle to 'find signs' that can be deciphered. ${ }^{16}$ Several pictures in the coltection adopt this point of view, and
13-Other menubers of the Dufferin famil chose more common media, such as portraiture, for recording impressions of their sojourn. Lady Dufferin writes, in connection will her daughter: 'Nesly is doing a series of portraits in chalk, and Major Cooper la member of the Viccroy"s staff provides her with models. She did on: of the jhampani men with great success, bu at the first sitting given her by a second model, a wild man wrapped in a sheet, he fainted, and having first subsided into an arm-chair he next rolled on to the floor and lay with bis head under his wing. The jemadar had gone to dinner, and Nelly an ther maid were left for some time vainly calling for assistance, and doing their little best to resuscitate the victim, who decline all their pressing offers of brandy and water. and would have no remedy but fresh air' (OVL 1.145).

14 - Susnus Soutag on Photograplyy, Londor Allen Lane 1978, 4 .

15-Barthes, 'The Eiffel Tower', 4, 17.

16-Ibid., 10. 
17 - Linnel Lambourne, fictorian Pitrungy, L. don: Phaidon 1999, 151.

$15-$ Lambourne, 163 have clearly been influenced by the all-encompassing panoramic paintings in vogue at the time. Although the panorama was conceived as an artistic trope in the eighteenth century, Lionel Lambourne claims that it became most popular during the Victorian period, and that its emergence heavily affected visual perceptions of the time. ${ }^{17} \mathrm{He}$ examines a well known panoramic painting, by Robert Baker (1739-1806), a 360-degree view of Edinburgh as seen from Calton Hill (1789); this perspective also resembles that offered by the Eiffel Tower. Baker predicted that his discovery would set art free, for no longer would painting be confined by the limits and proportions of a frame: spectators visiting these pictures could imagine that they were actually there. This aspect was, for example, used by female colonisers in Australia who were attempting to convey their surroundings to people in Britain. ${ }^{18}$

In her journal Lady Dufferin clearly wishes to recreate a vivid portrait of India for her mother; thus she embellishes her descriptions with familiarly exotic intertextual markers. While visiting Lahore she notes: "First we saw the Serai, or great house of entertainment for men and beasts, a place such as the Arabian Nights' travellers used to put up in' (OVL 1.118); she also conveys familiarity by referring to well known Irish locales. Writing from Calcutta, she forewarned her mother: 'Please to remenber that I am in India, for if you don't keep that fact before your eyes you will not find the following description of a flower show at all interesting. You will only imagine that $I$ am in the County Down, and will wonder why I should tell you anything so commonplace' (OVL 1.53). Her prose does not always rise to the challenge in describing Indian landscapes. When travelling to Rawalpindi, she writes: 'As usual here, the mountains made a lovely background to the picture, while the foreground was well filled with Oriental and military colouring' (OVL 1.110). Arriving at Simla for the first time, she observes, 'The scenery is that of a real sea of mountains, rolling hills of various heights, with snowy peaks in the distance, but no very striking range or particular peak to appeal to one's imagination' (OVL 1.130). Lady Dufferin remarked upon the view from the window of the Viceregal lodge in Simla, from where she took photographs (figure 4):
Such a view from this house? Imagine looking through a frame of green leaves, and branches, and trunks of trees on to a rolling sea of mountains; the brown rippling hitls near at hand gathering in magnitude and in depth and variety of colouring as they get farther from you, and ending in a great range of glistening snow mountains, which look like crested waves dashing up against the clear blue sky; that is our view. $|\ldots|$ I even committed the almost sacrilegious act of trying to condense the splendid and gorgeously coloured map which Nature had spread before us into $8 \frac{1}{2}$ inches of plain brown photograph. (OVL, 2.30)

The comments are interesting for the insight they offer into how the Vicereine composed her view for the camera. She uses oceanic metaphors to convey ideas about depth of field, as well as the power of nature. She also admits that the recorded image, here resembling a polychromatic map, cannot do justice to the original. Maps, of course, are an important constituent of empire; they feature personal, political and ideological motivations. A cartographer can fix a region within designated borders, adjust a map's scale, introduce iconic symbolism (for example, a cross to represent a church), transportation routes such as roads and railway lines, or change the projection, in order to produce an individually tailored semiotic system; thus, as Christopher Board notes, "human artifice' influences the "creation of the representation", ${ }^{19}$ to ensure that the map becomes the territory. The same may be said of photographs: they are subject to personal, political and ideological motivations, which work together to convey a representation of reality that suits the photographer.
9- Christopher Hoard. "Naps as Models horley and Peter Huggett, London:

lechuen $196 \%, 671$. 


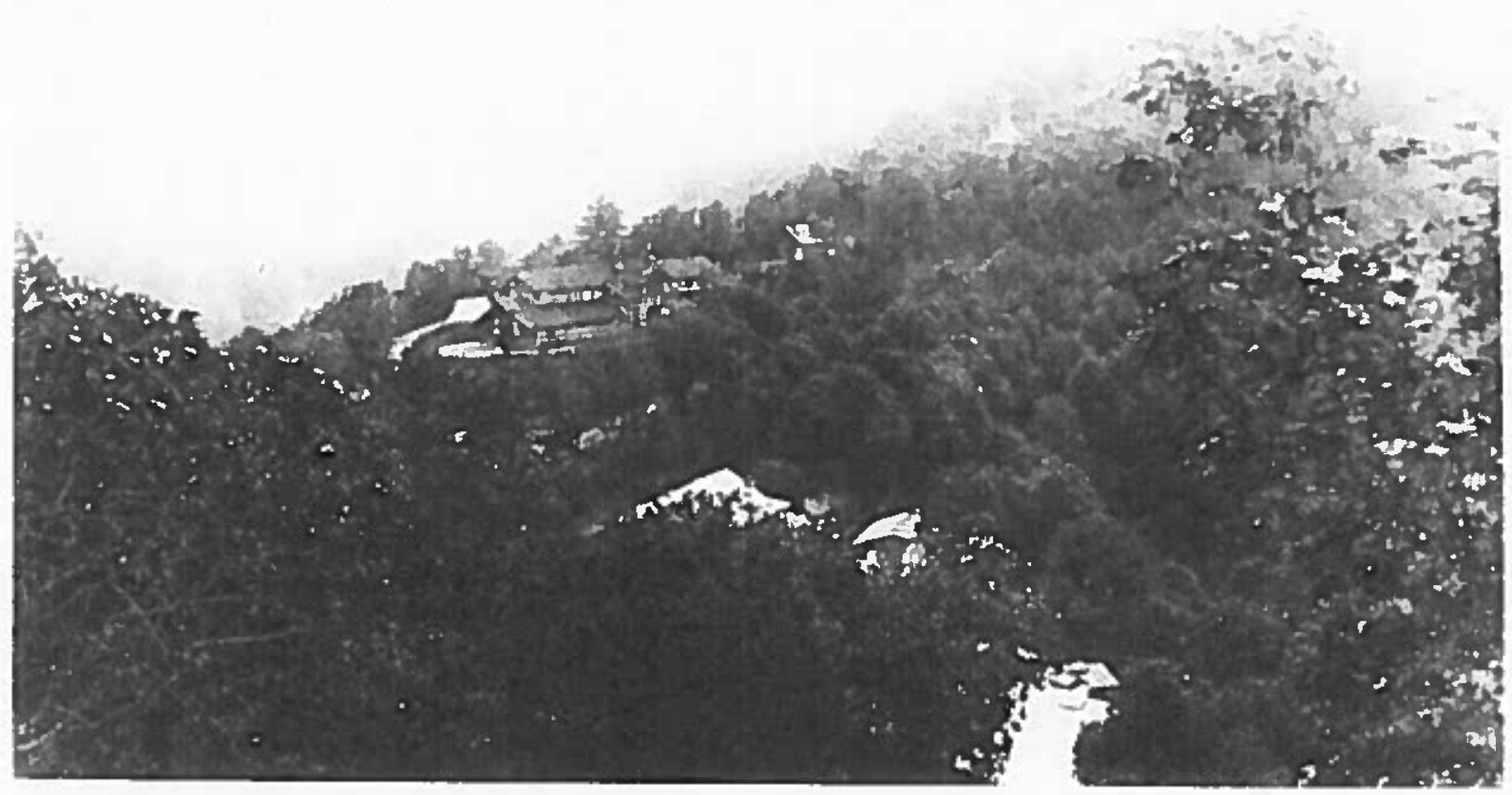

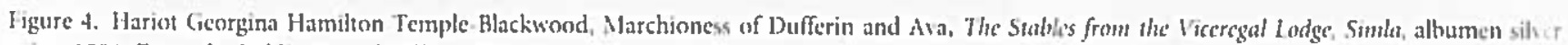
print, 1886. From the Public Record Office of Northern Ireland, by kind permission of the Marchioness of Dufferin and Axa.

At Simb the Dufferins held state balls and durbars, attended gymkhanas, visited their neighbours, and played tennis. Every activity involved a continual relay of ascents and descents; indeed official occasions necessitated the carrying of the heavy silver viceregal thrones; Lady Dufferin remarks to her mother: 'I thought you would like to know that even to this mountainous region we carry our state chairs and [...] are accompanied by all the symbols of our official dignity' (OVL 1.144-145). Elevation is an ever-present issue in Simla: the need to climb higher to obtain the best vantage point arouses Lady Dufferin's competitive instinct. She expresses exhilaration and triumph at reaching a nearby summit:

\section{We went up Prospect Hill, a peak very close to our own, and had from it a most magnificent view, the best I have seen here. Nothing gets in the way on any side, and one can see all round the ruggedness of the earth's surface near, and the high, higher, highest ranges of mountains in the far distance, the superlative degree of comparison being covered with snow. (OVL 1.154)}

From the prose passage, and even more so from the photograph, it is clear that the panoramic perspective, with its uninterrupted view, instils a feeling of exhilaration, achievement and power. It transforms Lady Dufferin into monarch of all she surveys: she adopts a 'magisterial gaze' from a perspective that recalls the privileged nineteenth-century American experience of the sublime: a visual trajectory from the elevated viewpoint of one who gazed from the uplands to the scenic panorama below-an 'Olympian' bearing, 'synchronically plotting the course of empire' through the ideology of 'Manifest Destiny'.20
20-Albert Boime, The Magisterial Grac: Manifest Destmy and Amcrican Landscap: Painting c 1830-1865, Washington, D.C Smithsonian Institulion Press 1991, I. 
1 - Michel Foucatte, Discipline and Panisit The Birth of the Prison, Trans. Alan heridan, London: Penguin 1991, 200.
23- The Politics of the Potenresque: Litcrasure, Lamdscape and Acshlotics Since 1720, Cambridge: Cambridge University 'ress 1994, 6.
The privileged omniscient perspective of the panorama attained significance for post-colonial theorists through Michel Foucault's analysis of the power of surveitlance to regulate and rule a society. In Discipline and Punish he recalls how surveillance was first introduced to Britain by Jeremy Bentham, who perceived it as a way to regulate both the poor and criminal classes. Foucault examines how the Panoptic Prison (the architectural manifestation of Bentham's ideological stance) facilitates the development of a self-regulatory society; it would induce in the inmate, as Foucault says, 'a state of conscious and permanent visibility that assures the automatic functioning of power'; 'he is seen', Foucault continues, "but does not see; he is the object of information, never a subject in communication'. ${ }^{21}$ The possibility of constant and complete visibility means the observed must monitor his or her behaviour in order to remain within the boundaries of acceptability set by the observers. Postcolonial theorists have used the panoptic model, as filtered through Foucault, to demonstrate how European colonisers manipulated and controlled subjugated peoples; within this context surveillance was initially perceived as a predominantly masculine activity endorsed by official and governmental bodies which sent male travellers and explorers to survey, map, document, and inventorise the colonies. The case of Lady Dufferin is interesting: according to nineteenth-century ideas concerning the passivity of women, she should be classified as an apolitical spectator of the empire, whose textual observations and representations do not contribute to the 'great game'; however, her photographs have the potential to overturn accepted gender-specific ideas about the implications of surveillance for colonial discourse: she may look up to uninhabited mountains, but clearly looks down, in panoptic mode, upon Indian society.

Lady Dufferin's manipulation of aesthetic representation was influenced by the artistic trope of the picturesque, as can be seen in a photograph of a temple near Annadale, Simla (figure 5). Her journal often features the adjective 'picturesque' to describe particularly pleasing scenes. The word also refers to a technique in painting, which was frequently used by nineteenth-century women travellers in order to deal with, and distance themselves from a colonial reality. Artistic principles concerning the picturesque endorsed the arrangement of elements in order to render them more aesthetically pleasing; Lady Dufferin's letters reveal that she composed some images with an aesthetic ideal in mind. Many of the photographs of indigenous people contribute to an image of India that reinforces preconceived ideas about British ascendancy: colonisers exuded a European sensibility, whereas the colonised were stereotypically Orientalised. Reality was manipulated in order to subscribe to European ideas concerning picturesque aesthetics.

In their introduction to The Politics of the Picturesque, Stephen Copley and Peter Garside argue that this aesthetic form transformed the social and political into the decorative; ${ }^{22}$ this idea is evoked frequently in Lady Dufferin's letters through the numerous incidents and events where India is experienced as a theatrical scene, emerging before her as a spectacle; the actors in Mandalay are a case in point, as are the bodyguards of the Viceroy at Simla (figure 6); their uniforms clearly embody indigenous influences; but the red tunic and high leather boots mark them out as servants of the Raj. At this late point in the nineteenth century the ceremonial and hierarchical evocations of the empire in India were reaching their zenith; as the Vicereine, Lady Dufferin was given an uninterrupted vantage point from which to observe this spectacle and performance. Clearly on their travels the Dufferins were exposed to the best that India had to offer, from the snow-capped Himalayas to the Ellora Caves to the majestic Taj Mahal. They visited Calcutta, Allahabad, Rawalpindi, Lahore, 


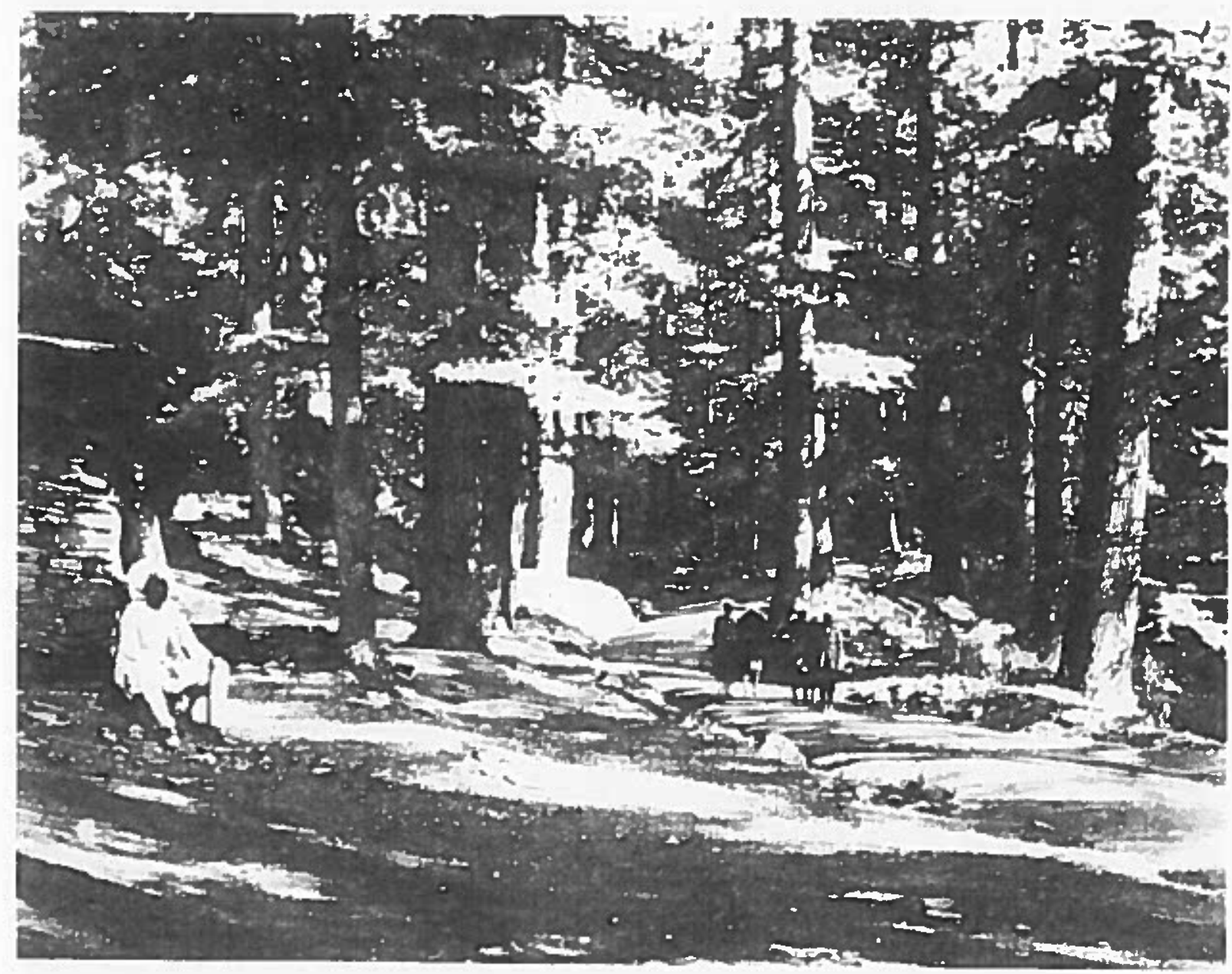

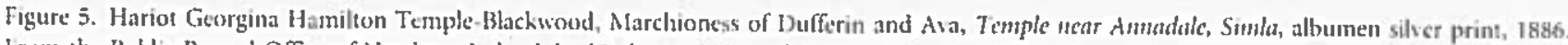
From the Public Record Office of Northern Jreland, by kind permission of the Marchioness of Dufferin and Ava.

Karachi, Amritsar, Simla, Nahun, Delhi, Rajputana, Agra, Lucknow, Burma, Madras, Bombay, Hyderabad, Mysore and Darjeeling. In each location everything seemed to be staged and arranged for the Viceroy and Vicereine, and their comfort was paramount. From among all the colonies, in India in particular the British were intensely aware of the impact which a scene of visual splendour could have on both coloniser and colonised; the imperative to rule was both modelled upon and facilitated by the magnificence of the orientalised image of the native princes, such as the Maharajah Holkar, who meets the Viceregal party in his court dress at Jodhpore. The Vicereine writes:

\begin{abstract}
The petticoats are in thick folds, and are alt made of pink muslin; halfway" down the skirt they are tied in with a scarf, so that at the bottom they stand straight out and sway about as the wearer moves. They are so full that when a man rides in them they fall quite naturally over each leg as if they were 'divided,' but in a carriage they are most awkward, and no ball dress was ever so difficult to tuck in as was the Maharajah's skirt when he followed the Viceroy into the beautiful yellow carriage awaiting him. The headdress worn with this is also very peculiar. It is red and yellow, and rather pointed. The Maharajah wore the Star of India collar and ribbon. [... 1 1 had a delightful companion in my carriage-the heir-apparent, aged six, dressed in red court petticoats, which he told me he found hot, and which he had only put on to show me. (OVL 1.234-5)
\end{abstract}

Such views help to consolidate an Arabian Nights vision of India to which the Vicereine was continually subjected.

Like many travellers who valued the picturesque, Lady Dufferin perceived the Orient as a commodity, which is revealed and aestheticised by trinkets and 




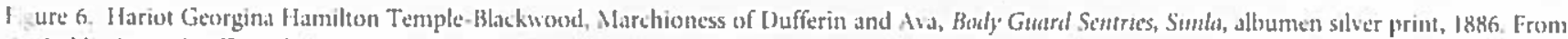
the l'ublic keoord Office of Northern Ireland, by kind persnission of the Mlurctioness of Dufferin and dva.

souvenirs. $A$ large number of these are evident in a photograph of her private desk and travelling cabinet in her boudoir in the Viceregal lodge (figure 7). It is rare that we are allowed glimpses into the personal lives of the upper classes-especially of one so emblematic of imperial power. The travelling cabinet, which sits above or behind the desk, has surfaces that are covered in dark velvet. It takes the form of a triptych, which seems to be foldable for ease of travelling; this item of furniture accompanied Lady Dufferin as she journeyed through India, thus serving as a omnipresent repository of personal mementoes of family and empire. If the image is read from the top down, there can be seen, in the centre, a photograph of Lady Dufferin from her Canadian sojourn, with winter coat and fur muff for her hands; standing opposite this is an official photograph of her husband. Between the two images there is a figure on a pedestal, inspired by La Source, a painting by Ingres (1856). The images of the Viceroy and Vicereine are flanked by other posed photos of female family members-possibly her two elder daughters. On the next level down there are head-and-shoulder shots of younger people-probably her other children, together with small ornaments of birds and dancing figurines, as well as a large pipe on the right. On the desk's surface there are other photographs, an inkwell, a small bell on the left, a travelling clock, and, in the centre, a bound notebook, possibly her journal. To the right of the desk there is a bookcase, while to the left there is a carousel containing large and medium-sized bound books and papers, including sheet music. At seated eye level, on top of the letter box, there is a cross-legged Buddha figure-a clearly recognisable Oriental object. It may 


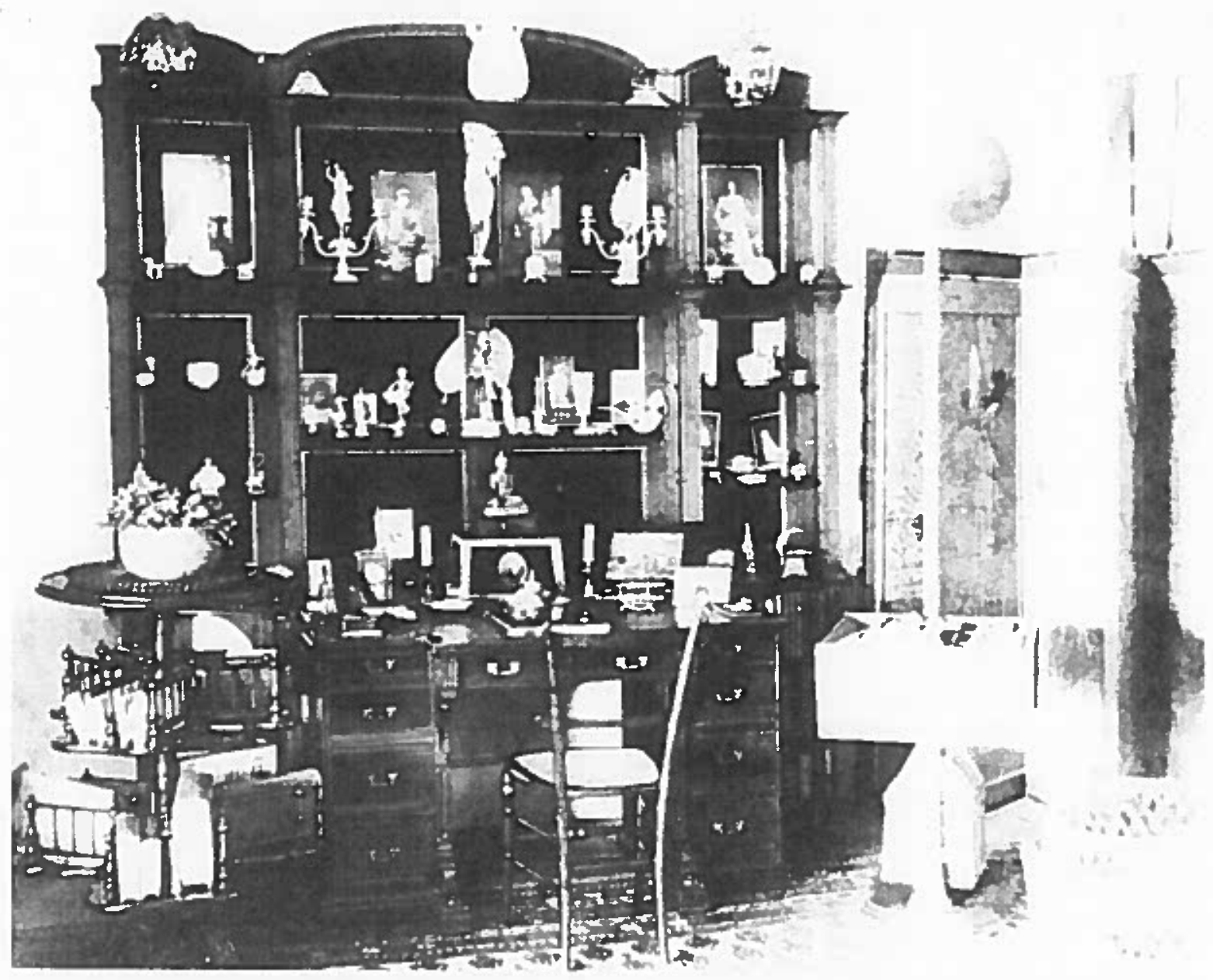

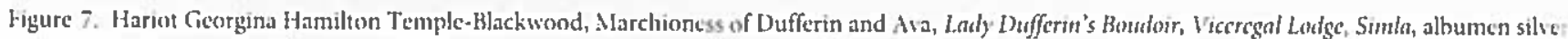
print, 1885. From lle Publie Record Office of Northern Ireland, by kind permission of the Marchioness of Dufferin and Awa.

have been a gift, or may luve been part of the meagre spoils from the palace in Mandalay. Its centrality in the composition is interesting, because it is the first thing to be seen when seated. It can be read as a constant reminder of empire and its acquisition or appropriation by the Vicereine for aesthetic purposes. When combined with the other objects, it speaks to some of the central themes running through Lady Dufferin's sojourn in India: her family, her photographs, her journal, and her direct daily encounter with the colonial world.

In his elegiac study of photography, Camera Lucida, Roland Barthes denies that the Photograph (a word he capitalises) is a 'copy' of reality; rather, he holds, it is 'an emanation of past reality', and that, from a 'phenomenological viewpoint', the 'power of authentication exceeds the power of representation' in the photograph. It is, he says, as a 'certificate of presence' that it has power and relevance. ${ }^{23}$ Lady Dufferin's photographs are those of a neophyte amateur, who is learning a new hobby and is sometimes embarrassed by the results. There were better photographs documenting the Dufferin Viceregency. Yet the Vicereine's images have immense value for what can be seen through the eyes of one who was at the absolute centre of British rule in India. They confirm how singular the subjective experience of photography can be, and show how a visual language can, while conforming to certain codes, open up a new mode of expression, particularly for women to participate in the discourses of empire.
23 - Rotand Barthes, Camera Lucidi: Reflections on Photography, trans. Kichard Howard, London: Vintage 1993, 88-89, 87 


\section{HISTORY OF PHOTOGRAPHY}

\section{Volume $30 \quad$ Number $4 \quad$ Winter 2006}

William Stirling and the Talbotype volume of the Amals of the Artists of Spoin

Hilary Macartme'

Taken from Life: Post-Mortem Portraiture in Britain 1860-1910

Audrey Linkman

The Subcontinent as Spectntor Sport: The Photographs of Hariot Lady Dufferin, Vicereine of India

Eadoom Agnew and Leon Lituach

The Gift of Form: Brassait and the Crypt of Saint-Sulpice

Meg Melvin

'Composition by the Rules'

Christion A. Puterson

Picturing Atrocity: Photography in Crisis

A Symposiun Report

Allison Moore

\section{REVIEWS}

Greg Fosfer-Rice - Maria Antonella Pelizzari - Elizabeth Edwards

Rebeca Swectman - Shame Lakin - Sophic Gordon

PUBLICATIONS RECEIVED

CONTRIBUTORS 


\section{Edum}

Grahum Snith

Sthoul of Atr History

9 The Somes

Unutersm of Si Androus

So Andrus KYlo GAR

Sconlemal

gs?20 st-andrut s.acouh

Assevelate Edus

Pegey Ann Kusmerz

Acumig Edicur 2006

Amu Arbor Mlichagan

U.S.A.

lihgumchidu

Book Resu'te Eilien

Satale Adamson

School of An Hrstors

9 The Sones

Unucrsuy of St Andstus.

St Andras Klle 9.AR

Scothamel

nat ta stamdre'us sucut

Former Editors:

Hein: K. Henisch

$(1977-1990)$

Mike Weaver S

Anne Hammond

(1991-2000)

Comeributung Editors:

Jan Baetonz

Peter Bumnell

Catherine Le Lorenzo

Elizabeth Edwards

lames Elkins

Colin Ford

Mlark Haw orth-Booth

ludith Kelles

Atme McCauley

Paolo Norello

John Mraz

Maria Antonella Peliz:ari

Christian A. Peterson

Mark B. Pohlad

Russell Roherts

Larry J. Schaaf

Sara Stevenson

Andraw Secgedv-M Las=ak

Roger Taylor

Mlike Ware

\section{HISTORY OF \\ PHOTOGRAPHY}

Subsctplaton hifommation

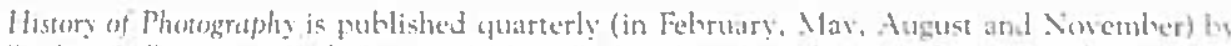

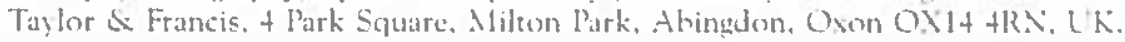

Annual institutional subscription 2007

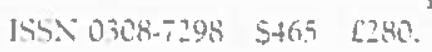

A persomal sulecription is awailalyle on application to Routledge Jouruals, Tav for \& Francis l'ersomal suberiptions must he recedued at a private address, and purchased with a peteonal checule or personal eredit card.

For more information on our journals and books pulvishing. visit our webste: http//wiw.tandficu,uk

History of Phorography (USPS permit number 599270 ) is pulliwhed guarterly (in

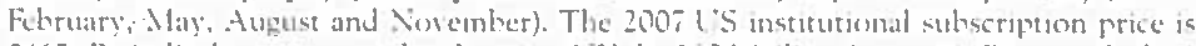

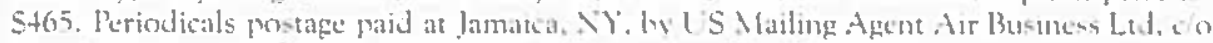

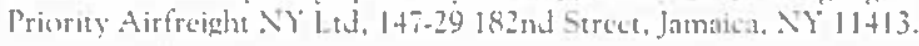

US Postmaster: Please send address clantes to tHPH Air Busines Lid. 6 a Priorit

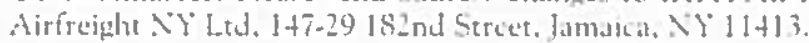

Dollar rates apply to suberibers in all cotuntres except the LiR and the Republic of frelind where the pound sterling price applics. All subseriftions are pavahle in advance and all rates include postage. Joumals are sem by ar to the I SA. Canidu. Mlexico. India. Japan and Australastil. Subscriptions are entered on an annual Fasis. i.e. Jamuarv to December. Payment may be madte hy sterling chepue, dollar cluecpue. ijuernational mones order, Sational Girn, or credit card (Amex. Visa, Mlastercard).

Orders originating in the following territories should be sent direct to the local distributor:

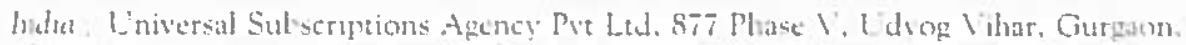

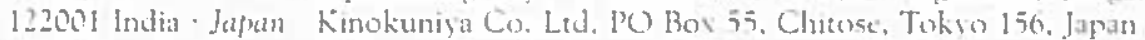
USA Candula/Metio Taylor \& Francis, Journals Department, 325 Chestnut Street.

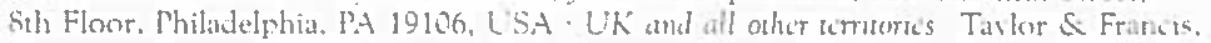
Customer Serviees. TEF hoforma Led. Sheepen Place, Culchestet, Essex CO3 3L[? LK.

Cover: Brassaï. Voltare de J. A. Houdon - Comidie-Françatse. Gelatin silver print. July 1945. $29.5 \times 19.4 \mathrm{~cm}$. Department of Jmate Collcctions, Stational Gallers of Art Lilorarv. Washinģutun Estate Brassai - RMN. 